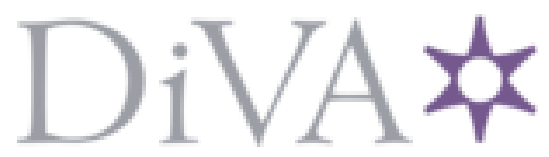

http://www.diva-portal.org

\title{
Preprint
}

This is the submitted version of a paper published in Human Relations.

Citation for the original published paper (version of record):

Sanchez-Famoso, V., Akhter, N., Iturralde, T., Chirico, F., Maseda, A. (2015)

Is Non-Family Social Capital Also (Or Especially) Important For Family Firm Performance?.

Human Relations

Access to the published version may require subscription.

N.B. When citing this work, cite the original published paper.

Human Relations: http://hum.sagepub.com/

Permanent link to this version:

http://urn.kb.se/resolve?urn=urn:nbn:se:hj:diva-2523 1 


\section{Is Non-Family Social Capital Also (OR ESPECIALLy) IMPORTANT For FAMILY Firm PERFORMANCE?}

Valeriano Sanchez-Famoso

University of the Basque Country UPV/EHU

Finance Economy I Department

C/ Elcano, 21; E48008 Bilbao, Spain

E-mail: valeriano.sanchezfamoso@ehu.es

Naveed Akhter

Jönköping International Business School

Center for Family Enterprise and Ownership - CeFEO

PO Box 1026

SE-551 11 Jönköping, Sweden

E-mail: naveed.akhter@jibs.hj.se

Txomin Iturralde

University of the Basque Country UPV/EHU

Finance Economy II Department

Avda. Lehendakari Agirre, 83; E48015 Bilbao, Spain

E-mail: txomin.iturralde@ehu.es

\section{Francesco Chirico}

Jönköping International Business School

Center for Family Enterprise and Ownership - CeFEO

PO Box 1026

SE-551 11 Jönköping, Sweden

E-mail: francesco.chirico@jibs.hj.se

Amaia Maseda

University of the Basque Country UPV/EHU

Finance Economy I Department

Avda. Lehendakari Agirre, 83; E48015 Bilbao, Spain

E-mail: amaia.maseda@ehu.es 


\title{
Is Non-Family Social CAPITAl Also (OR ESPECIALLy) IMPORTANT For FAMILY Firm PERFORMANCE?
}

\begin{abstract}
This study investigates the effects of both family and non-family social capital on firm performance. Specifically, we contend that non-family social capital has a stronger effect than family social capital and also serves as a mediator between family social capital and firm performance. Using a sample of 172 Spanish family firms that includes two respondents per firm, we test a structural model that confirms our hypotheses. Our results extend the understanding of social capital beyond family firms by exploring both family- and nonfamily-based social relationships in a context in which social factors are predominant.
\end{abstract}

Keywords: Family firms, family social capital, non-family social capital, firm performance, internal social capital

\section{INTRODUCTION}

Social capital (SC) is one of the most prominent concepts in the field of sociology (e.g. Coleman, 1988; Granovetter, 1973; Portes, 1998; Putnam, 1993). Over the years, it has been applied to the literature on organisations (e.g. Nahapiet and Ghoshal, 1998; Tsai and Ghoshal, 1998), strategy (e.g. Sirmon and Hitt, 2003), entrepreneurship (Carr et al., 2011; Casson and Giusta, 2007), and family businesses (Arregle et al., 2007; Chirico and Salvato, 2008; Salvato and Melin, 2008; Zahra, 2010). SC is defined as 'the network of relationships possessed by an individual or social unit, and the sum of actual and potential resources embedded within, available through and derived from such network' (Nahapiet and Ghoshal, 1998: 243). Nahapiet and Ghoshal (1998) and Tsai and Ghoshal (1998) identified three dimensions of SC, all of which are crucial to access and leverage the resources inherent in social relationships (Villena et al., 2011). These dimensions are structural (the extent to which group members are connected - forms of connections among actors) (Burt, 1992; Inkpen and Tsang, 2005), relational (the quality of these connections - trust and trustworthiness)

(Granovetter, 1973, 1985; Nahapiet and Ghoshal, 1998; Tsai and Ghoshal, 1998), and cognitive (the extent to which group members share a common perspective or understanding mutually beneficial common goals among actors) (e.g. Inkpen and Tsang, 2005). 
Prior research has identified family firms - organisations in which ownership and management are concentrated within a family, with multiple family members striving to maintain intra-organisational family-based relatedness (Arregle et al., 2007) - as one of the most vital and fertile grounds for the development of strong relationships (Chirico and Salvato, 2014; Habbershon and Williams, 1999; Salvato and Melin, 2008; Sirmon and Hitt, 2003). For instance, Arregle et al. (2007: 77) suggest that 'SC developed in the family is probably one of the most enduring and powerful forms of SC'. However, despite increased research interest, the effect of family SC (the strength of relationships among family members) on firm outcomes remains unclear (e.g. Arregle et al., 2007). Additionally, the impact and importance of non-family SC (the strength of relationships among non-family members) on firm performance has been largely ignored (see Arregle et al., 2007; Sonfield and Lusssier, 2009b; Zahra, 2010).

Thus, this study aims to explore how and to what extent both family and non-family $\mathrm{SC}$ affect firm performance. This issue is especially important because of the central roles both family and non-family members play in family firms (e.g. Arregle et al., 2007; McConaughy, 2000; Sharma, 2008; Stewart, 2003) and the fact that these groups often coexist (see Distelberg, 2008; Miller et al., 2014; Mitchell et al., 2003; Vandekerkhof et al., 2014). Although family firms can be diverse for a number of reasons, both family and non-family groups are crucial to study family and non-family SC and their related potential firm outcomes. The family group may contribute to firm performance through family members' strong and enduring ties, shared visions and goals, and a sense of shared responsibility and collective action (Habbershon and Williams, 1999; Sirmon et al., 2008). In contrast, the nonfamily group, which is less emotionally attached, may have the ability to view the business more objectively, providing diverse knowledge and greater professionalism (Salvato et al., 2010; Sharma and Irving, 2005). Thus, if both family and non-family groups have the 
potential to foster family firm performance, how do (or should) they work in conjunction? Further, given the 'outsider role' played by non-family members (see Salvato et al., 2010), does non-family SC mediate the translation of family SC into firm performance positively or negatively? As such, is non-family SC also (or especially) important for family firm performance?

To address these questions, we rely on a dataset of 172 Spanish firms, including two respondents per firm. Our results offer several important contributions. First, we contribute to the understanding of family SC and non-family SC and their effects on firm performance. To the best of our knowledge, this is the first empirical study to focus not only on family SC but also on non-family SC in family firms. Second, our study shows that non-family SC has a stronger effect on firm performance than does family SC, thus emphasising the central role of the former while opening up interesting avenues for future research. Third, we theorise (and our results confirm) that non-family SC also mediates the positive effect of family SC on firm performance. Fourth, we observe that family firms, while often depicted as homogeneous, are actually diverse (e.g. Sharma, 2004). This finding offers another important insight and a better understanding of family firms.

The remainder of this paper is organised as follows. First, we present the literature related to SC and family firms. Then, we develop our arguments, leading to four hypotheses on SC and family firm performance. Next, the employed method is presented, and the results are reported. We close with a discussion of our study's contributions, as well as its limitations and directions for future research.

\section{THEORETICAL FRAMEWORK}

Historically, SC has been researched in the study of families, or relations between parents and children, as well as the study of societal development in general (e.g. Coleman, 1990; Portes, 1998; Putnam, 1993). Nevertheless, the breadth of the concept has led to its 
exploration as a unique resource. Coleman (1990) framed SC as a valuable asset that stems from access to resources made available through social relationships. By allowing people to act collectively, SC reflects the value of relationships: It exists among people and organisations and provides its holders with potential opportunities (e.g. Nahapiet and Ghoshal, 1998; Stam et al., 2014). Nahapiet and Ghoshal (1998) and Tsai and Ghoshal (1998) synthesise SC in three dimensions: structural, relational, and cognitive. First, the structural dimension describes the extent to which members are interconnected. This dimension includes the network actors and the strength of ties among members of a collective (Pearson et al., 2008). Stated differently, it relates to the number of connections and relationships, as well as the hierarchical structure of social capital. In Granovetter's (1992) terms, structural embeddedness provides 'more efficient information spread about what members of the pair are doing, and thus better ability to shape that behaviour' (p. 35). Second, the relational dimension reflects accumulated events and historical interactions that create trust, reciprocity, norms, and identification as a member of the group. For instance, Granovetter (1992) identified the relational embeddedness of an interaction as the degree to which parties in an exchange consider one another's needs and goals. That is, this dimension reflects accumulated events and historical interactions that create trust and trustworthiness (Tsai and Ghoshal, 1998). Trust is an attribute of a relationship, and it is facilitated when one party demonstrates a sincere desire to help the other party in a relationship, without any expectation of reciprocity. In this sense, collective trust allows group members to rely on each other and, more generally, helps solve the everyday problems of cooperation and coordination (Kramer et al., 1996). Trustworthiness is an attribute of an individual actor involved in the relationship (Barney and Hansen, 1994). Finally, the cognitive dimension refers to 'the resources providing shared representations, interpretations, and systems of meaning among parties' (Nahapiet and Ghoshal, 1998: 244). It offers a shared vision that embodies collective goals 
and aspirations (Tsai and Ghoshal, 1998). High levels of this dimension give members a common perspective that enables them to perceive and interpret events in similar ways (Boland and Tenkasi, 1995; Nohria, 1992). This dimension helps explain how groups achieve a common sense of belonging. Thus, the cognitive dimension stresses the significance of a foundation of common understanding that enables members to act appropriately within a structure. It is not enough to have information about the context; the agent also needs to be able to interpret that information correctly.

In the study of SC, the context of family firms - firms in which a family possesses a significant ownership stake and in whose operations multiple family members are involved (Chirico et al., 2011b; Sirmon et al., 2008) - provides important insights. While definitions of family firms may vary among scholars (Uhlaner et al., 2012), these firms share a fundamental similarity. Social structures and affective commitments are particularly salient in family firms because of the intersection of the family and business systems (e.g. Sirmon and Hitt, 2003). For example, Redding (1990) suggests that family firms are governed through key personal relationships among family and non-family members. Such relationships are characterised by a deep concern for normative, mutually responsible behaviours that 'binds' participants to the faithful service of a culturally entrenched objective. For this reason, family firms are depicted as socially and commitment-intensive organisations whose members (especially family members) highly value social relationships within the business enterprise and harbour a strong sense of emotional attachment to the business (Chirico et al., 2011a; Gomez-Mejia et al., 2007). Additionally, it is well known that family firms play an important role in society by creating wealth and economic prosperity (Arregle et al., 2007; Miller and Le Breton Miller, 2005; Sirmon and Hitt, 2003). The importance of family firms is evident, as they are prevalent worldwide (e.g. Acquaah, 2011; Cesinger et al., 2014). In fact, estimates suggest that $65 \%$ to $90 \%$ of all companies worldwide are family firms (Arregle et al., 2007). In particular, across 
Europe, about $70 \%-80 \%$ of enterprises are family businesses, and they account for about $40 \%-50 \%$ of employment (GEEF, 2009).

Next, we develop our arguments about SC in family firms. We present our hypotheses by sequentially arguing for the importance of family SC, non-family SC, family SC versus non-family SC, and non-family SC as a mediator.

\section{HYPOTHESIS DEVELOPMENT}

Casson and Giusta (2007) argue that different types of groups are capable of serving different purposes. The personal relationships that exist in groups, which are based on a history of interactions, represent an important source of SC (Pearson and Carr, 2012). Many family firms are characterised by the presence of both family and non-family members (see e.g. Distelberg, 2008; Miller et al., 2014; Mitchell et al., 2003; Vandekerkhof et al., 2014), who form two distinct but complementary and important groups that, through their relationships (both family and non-family structural, relational, and cognitive dimensions), may facilitate the actions required to improve performance (Arregle et al., 2007; Nahapiet and Ghoshal, 1998; Tsai and Ghoshal, 1998). Next, we elaborate on this insight to develop our hypotheses.

\section{Family Social Capital and Firm Performance}

In this section, we argue that family SC positively affects family firm performance. Family SC is viewed as a source of competitive advantage that generates family firm wealth and creates value (e.g. Habbershon et al., 2006). Family SC binds family members together and makes social interaction easier (Arregle et al., 2007; Chirico and Salvato, 2014). As argued by Bubolz (2001: 130), 'the family is a source, builder, and user of social capital'. This is because family members are deeply committed to the business (Eddleston, 2012; Hall, 2003), and, as such, their relationships constitute a resource that can be used to maximise family firm performance. Accordingly, scholars believe that relations among family members 
encourage an ideal environment that fosters high levels of SC (Arregle et al., 2007; Coleman, 1988) and thus firm performance (Sorenson et al., 2009).

For instance, Cross and Prusak (2002) note that the distinctive set of family resources created by family SC provides a competitive advantage for family businesses. First, the structural dimension of family SC (the pattern of connections among family members) is crucial and facilitated by the strong ties that exist among relatives. Second, the relational dimension of family SC provides the necessary elements to work towards superior firm performance. In this regard, family firms exhibit the characteristics and attitudes of trust, friendship, respect, and reciprocity, developed through a history of interactions; these are engendered in the family group and decrease opportunistic behaviour (e.g. Coleman, 1988; Salvato and Melin, 2008; Sorenson and Bierman, 2009). Third, in terms of the cognitive dimension, the presence of family members with similar cultural and goal-setting objectives provides the advantage of facilitating the exchange of resources, and therefore enhances performance, because all parties see the potential value of the integration and combination of their resources (Chirico and Salvato, 2008; 2014). Thus, family SC makes the collective business work better while allowing complementary resources to be accessed and shared. Accordingly, we contend that family members' ability to work together harmoniously and efficiently facilitates the achievement of better firm performance. In formal terms:

Hypothesis 1: Family social capital positively influences family firm performance.

\section{Non-Family Social Capital and Firm Performance}

Here we argue that non-family SC is also a positive antecedent of family firm performance. That is, the presence of non-family members and the three related forms of nonfamily SC (structural, relational, and cognitive) are also important in fostering positive performance outcomes in family firms (Hall and Nordqvist, 2008; Salvato et al., 2010). However, although the non-family group plays an important role, research on non-family groups within family firms is surprisingly scarce. Chua and colleagues (2003) argued that 
family managers consider relationships with non-family managers to be nearly as important as succession-related concerns. As suggested by Sharma (2008), research on non-family employee relationships is crucial to further the understanding of family firm SC and outcomes. In fact, non-family members secure beneficial SC for family firms by setting clear financial firm objectives; promoting a professional, transparent, and trusting environment; developing working routines and understanding; using their extended networks outside the family; and interacting with diverse external stakeholders (e.g. $\mathrm{Ng}$ and Roberts, 2007; Oh et al., 2006; Watson et al., 1998; Zahra, 2010).

As such, the structural, relational, and cognitive relationships among non-family employees supply a family firm with resources that strengthen firm capabilities (e.g. Adler and Kwon, 2002; Bubolz, 2001; Granovetter, 1973, 1985) and even help the family survive during difficult times (Miller et al., 2009; Miller and Le Breton-Miller, 2005; Salvato et al., 2010). Through their relationships and diversity of experience, non-family members provide greater heterogeneity (Watson et al., 1998) and professionalism (Dyer, 1988; Hall and Nordqvist, 2008; Stewart and Hitt, 2012), which facilitate firm performance (Chua et al., 2012; Nahapiet and Ghoshal, 1998). These arguments suggest:

Hypothesis 2: Non-family social capital positively influences family firm performance. Family Social Capital Versus Non-Family Social Capital

The arguments above advance the notion that both family SC and non-family SC positively affect family firm performance. However, in this section, we argue that, given that the non-family group has the advantage of being more diverse, heterogeneous, and professional than the family group, non-family SC, with its structural, relational, and cognitive dimensions, has the potential to generate better performance in family firms. That is, it not only facilitates firm performance but also amplifies it.

First, the diversity and heterogeneity of non-family members encourages more entrepreneurship and innovation, and thus improves firm performance (Westlund and Bolton, 
2003). Second, non-family members' professionalism and the related greater decision-making objectivity (Salvato et al., 2010) and strong networks outside the family (Stewart, 2003) help them to be more strongly focused on the business side while efficiently and collectively using their own and firm resources to increase firm performance (Stewart and Hitt, 2012). In this respect, Dyer (1986: 102) views professional management as a 'rational alternative to nepotism and familial conflicts that infect a family business'. The more professional the nonfamily group is, the more knowledge it will be able to assimilate, value, and apply from this central structural position (Cohen and Levinthal, 1990). Third, the salaries of non-family members are often linked to firm performance (e.g. bonuses) (e.g. Allen and Panian, 1982; Gomez-Mejia et al., 2001). In contrast, family members (e.g. family chief executive officers [CEOs]) are often paid less, and their compensation is less sensitive to firm outcomes (Gomez-Mejia et al., 2003; McConaughy, 2000). Thus, we expect non-family groups to rely less on path dependency and invest more effort and energy into efficiently translating their non-family SC into better firm performance relative to family member groups. Based on the arguments above, we propose:

Hypothesis 3: The effect of non-family social capital on firm performance is stronger than the effect of family social capital.

\section{Non-Family Social Capital as a Mediator}

Building on our previous hypothesis, we theorise that non-family SC is not only a stronger antecedent of family firm performance than is family SC but also that it partially mediates the relationship between family SC and family firm performance. In family firms, the connection between family members and non-family members should be (and often is) intense and durable (e.g. Arregle et al., 2007; Zahra et al., 2004). This is because family firms exhibit a desire to maintain strong relationships with non-family members who provide the firm with critical resources (Chirico et al., 2011a; Miller et al., 2009). In particular, as previously mentioned, the positive effect of family SC on firm performance is primarily 
derived from the close social interactions among family members that encourage them to value each other's ideas and perspectives in solving problems and seizing opportunities (Arregle et al., 2007; Salvato and Melin, 2008; Sirmon and Hitt, 2003). However, the mere presence of strong family ties might not always generate positive (or remarkably positive) performance outcomes, for instance, when such ties promote path dependency and restrain family members from following alternative courses of action (Arregle et al., 2007; Chirico et al., 2011b). In addition, strong social relationships among family members might foster family members' desire to nurture and preserve socio-emotional wealth - the nonfinancial aspects of the firm that meet the family's affective needs, such as family control, perpetuation, and identifying with the business - which may hamper initiatives that are essential to increasing family firm performance. The family may thus 'act more conservatively by avoiding [risky] business decisions' (Gomez-Mejia et al., 2007: 106).

Therefore, to maximise firm performance, family members may need not only to exploit each other's knowledge and resources but also to recognise, value, and contribute to the knowledge and resources provided by the firm's non-family group (Chirico et al., 2011a; Ram, 2001; Sonfield and Lusssier, 2009b; Zahra, 2010). Family SC is more likely to yield stronger firm performance if it is used to exploit the knowledge and relationships of nonfamily members. In other words, non-family SC has the potential to connect the family to firm outcomes. For instance, as stated by Sorenson et al. (2009: 239), the 'social structure of family firms supplements frequent close relationships', leading to increased SC (both familyand non-family-based), with consequent improvements in firm performance. To this end, 'family members need to be open, that is, support initiatives, new challenging ideas, radical thoughts and actions, or even simple suggestions when they contrast with beliefs of the dominant coalition...by supporting open and collaborative exchanges of information at all levels [both family and especially non-family levels]' (Chirico and Salvato, 2008: 179). 
Thus, we predict that non-family SC will mediate the relationship between family SC and firm performance. In formal terms:

Hypothesis 4: Non-family social capital mediates the family social capital/firm performance relationship.

\section{METHODS}

\section{Sample}

We conducted this study on Spanish family firms included in the SABI (the Iberian Balance Sheet Analysis System) database in January 2013. We chose Spanish firms because according to estimations provided by the Spanish Family Enterprise Institute (2009), the approximately 2.9 million Spanish family enterprises (out of a total of 3.4 million enterprises) generate $70 \%$ of the total Spanish gross domestic product (GDP) and employ nearly 13.9 million people (representing around $75 \%$ of total private employment in Spain). The final report of the European expert group in the field of family enterprises (GEEF, 2009) indicates that Spain has more family enterprises than average in Europe. In addition, the Spanish government has fully eliminated inheritance and gift taxes and has developed several grants for the preparation of family protocols and succession planning in family businesses (GEEF, 2009). In addition to public policy activities, it is worth stressing that Spain has a relatively large network of private and public institutions dealing with issues relevant to family businesses. Furthermore, Spain is a Country in which people are likely to rely on familial arrangements (Steier, 2009).

In this study, based on the common selected criteria of ownership and management control (e.g. Chirico et al., 2011b; Ng and Roberts, 2007), a company was regarded as a family firm if a family (1) owns more than $50 \%$ of ordinary voting shares and (2) manages the firm. To find firms meeting these two conditions, we conducted an exhaustive review of shareholding structures (percentages of common stock) and composition (surnames of 
shareholders; for a similar approach, see Gomez-Mejia et al., 2001; Perez-Gonzalez, 2006) ${ }^{1}$. Additionally, we excluded those companies affected by insolvency, winding-up, liquidation, or zero activity, as well as listed companies. In addition, we verified that at least two family members and two non-family members were employed in the firm. Finally, we focused on firms that provided financial information. Based on these conditions, the population under study consisted of 1,122 non-listed Spanish family firms.

A questionnaire, which was pretested on 15 family firms from different sectors, was used to obtain information that would be unavailable or difficult to acquire for non-listed firms. The questionnaire collected information on the variables required for the study. In particular, these variables included information regarding relationships within each group of employees (the family and non-family groups). Data were collected by means of telephone interviews, a method that ensures a high response rate. To guarantee the highest possible number of replies, managers were made aware of the study in advance by means of a letter stating the purpose and importance of the research. When they were reluctant to reply, telephone interviews were scheduled in advance. We contacted two top executive managers one from the family and one not from the family - from each company to collect information about the relationships among family and non-family members. We protected the respondents' anonymity by assuring in the cover letter that accompanied the survey that responses would be confidential. We received responses from 232 family firms $(20.70 \%$ of the sample), with full dual responses from 172 family firms; the latter constitute our final sample. A non-response analysis revealed no statistically significant differences between respondents and non-respondents.

As Table 1 shows, the interviewees were managers (in the family group, $50.50 \%$ were the CEOs and $49.50 \%$ were managers from different areas; in the non-family group, $49.50 \%$

\footnotetext{
${ }^{1}$ In Spain, people have two surnames. The first is the surname of the father and the second is the first surname of the mother. As such, family relationships between shareholders are evident.
} 
were financial managers, $41.70 \%$ were managers from other areas, and $8.80 \%$ were CEOs).

Table 1 also shows a brief description of our sample. Regarding company age, only $6 \%$ of the family firms surveyed have been in existence for less than 10 years. In other words, the majority of the companies in our sample have gone through their early years and have had the opportunity to establish relationships among their employees. With regard to company size, these firms range from 10 to 500 employees, with an average of 93 employees and a median of 67 employees. We focus on firms with at least 10 employees, because the presence of at least 10 employees can reinforce the use of communication at work (Sorenson, 2012), and a maximum of 500 employees, firms with more than 500 employees lose opportunities for relational links between family members and non-family members (Basco, 2013). In our sample, $23 \%$ of the companies have between 10 and 50 employees, $72 \%$ have between 50 and 250 employees, and only $5 \%$ have more than 250 employees. Thus, most of the sample companies are small and medium-sized enterprises. In terms of generations managing the firm together (generational involvement), 56\% of the responding firms are managed by only one generation, $40 \%$ by two generations, and $4 \%$ by three or more generations. Regarding the number of generations involved, $37 \%$ firms are held by the first generation of the family that launched the business, $41 \%$ have been passed down to the second generation, $12 \%$ to the third generation, $8 \%$ to the fourth generation, and $2 \%$ to the fifth generation or later. Finally, $48 \%$ of companies belong to the manufacturing sector and $52 \%$ to the service sector.

\section{--- Insert Table 1 about here ---}

\section{Data Analysis}

The model presented in Figure 1 was tested using structural equation modelling (SEM). Steenkamp and Baumgartner (2000) highlighted two main advantages of this technique. First, structural equation models allow for measurement error to be explicitly incorporated into models and for its influence on the degree of fit to be analysed. Second, 
unlike in multiple regressions, relationships among multiple independent and dependent constructs can be studied simultaneously (Anderson and Gerbing, 1988), which is especially relevant to testing mediating effects. While many other techniques enable scholars to analyse only one layer of linkages between independent and dependent variables at a time, SEM represents the state-of-the-art approach to testing for mediated relationships among constructs, particularly when multiple items have been used to capture each construct (e.g. Iacobucci et al., 2007), and especially with non-normal data (Alavifar et al., 2012). The hypothesised structural equations models were tested using EQS 6.2 (Bentler, 1995) with the raw data as inputs. Raw data screening showed evidence of a non-normal distribution (Mardia's coefficient normalised estimate $=34.26$ ). Although other estimation methods have been developed for use when the normality assumption does not hold, we followed the recommendations of Chou et al. (1991) and Hu et al. (1992) to correct the statistics rather than using a different estimation model. We followed Satorra and Bentler's (1988) robust statistics approach, using SEM and the robust maximum likelihood estimation method.

\section{Measurement of Model Variables}

Our constructs were adopted from previously validated scales. As mentioned, the items were pre-tested with a convenience sample of 15 family firms. The pre-test created a highly reliable instrument (Cronbach's $\alpha$ ranging from 0.71 to 0.85 ). The study's variables and items are reported in Appendix I.

\section{Dependent and Independent Variables}

First, it is important to recognize that performance is often described as a multidimensional concept (e.g. Venkatraman and Ramanujam, 1986). In particular, two types of performance measures can be distinguished in the literature: financial or objective measures such as return on assets (ROA) and return on investment (ROI), and non-financial or subjective measures such as owners' overall satisfaction and nonfinancial goals (Lumpkin and Dess, 1996). 
However, given that perceptual measures are often recommended for studies of human behaviour and relationships (e.g. Spector, 1994), and given that a subjective assessment of performance in family firms has been shown to correlate highly with objective performance data (e.g. Venkatraman and Ramanujam, 1987), in the present study, we used a subjective (self-reported) measure of firm performance. In particular, we used a two-scale measure developed and validated by Sorenson et al. (2009) and subsequently used in many other studies (e.g. Vallejo-Martos, 2009). As shown in Appendix 1, using an 11-point Likert-type scale (ranging from $0=$ strongly disagree to $10=$ strongly agree), respondents answered questions pertaining to their firm's level of profitability and financial position compared to those of their major competitors during the last five years.

Second, based on the existing literature, we used a five-point Likert-type scale (ranging from $1=$ strongly disagree to $5=$ strongly agree) for all the other variables (structural, relational, and cognitive dimensions) (see Appendix I). Following Tsai and Ghohal (1998), we adopted a set of two items to measure the structural dimension of family $S C(\alpha=0.80)$ and non-family $S C(\alpha=0.71)$. The two items reflect the extent to which group members are connected to each other (social interactions: time spent; social interactions: close contact) (Inkpen and Tsang, 2005; Pearson et al., 2008). We followed Cuevas-Rodriguez et al. (2013) and Tsai and Ghoshal (1998) to measure the relational dimension of family SC ( $\alpha=$ $0.84)$ and non-family $S C(\alpha=0.80)$. The two items focus on the quality of the group members' relationships (trust: reliability; trustworthiness: promise keeping) (Fukuyama, 1995; Leana and Van Buren, 1999). Finally, we followed Nahapiet and Ghoshal (1998) and Tsai and Ghoshal (1998) to measure the cognitive dimension of family $S C(\alpha=0.74)$ and nonfamily $S C(\alpha=0.85)$ with a set of two items measuring the extent to which a group's members share a common perspective or understanding (shared ambitions and values; shared objectives and mission) (Inkpen and Tsang, 2005). The family and non-family SC scales represent 
second-order reflective constructs (Casanueva et al., 2010; Sanchez-Famoso et al., 2013; 2014), that is, multidimensional concepts that consist of a number of more concrete (or firstorder) sub-dimensions or components. More specifically, this paper conceptualises both family and non-family SC as three-dimensional, second-order reflective measures. These second-order conceptualisations are consistent with the majority of existing multidimensional constructs (Carr et al., 2011; Law et al., 1988).

\section{Control Variables}

We controlled for five variables that may have affected our results: company size, company sector, company age, family generation in control, and family involvement. Company size was measured using the natural log of total assets. The company sector was operationalised as a dummy variable that took the value of 1 for manufacturing firms and 0 for service firms, following the Spanish industrial classification (CNAE - National Classification of Economic Activities) $)^{2}$. Company age was measured using the natural log of firm age (Zahra and Nielsen, 2002). Family generation in control was operationalised with a single-item question that asked respondents to indicate which generation currently manages the firm (Chirico and Salvato, 2014; Ling and Kellermanns, 2010). Finally, as previously mentioned, our firms are all family owned; however, we controlled for family involvement using the percentage of family members on the top management team (TMT), given its potential effect on family firm performance (e.g. Chirico and Bau, 2014).

\section{RESULTS}

Following the methodological recommendations of Anderson and Gerbing (1988), the analysis of the results includes two stages: evaluating the validity of the measurement model (confirmatory factor analysis) and testing the hypotheses (Anderson and Gerbing, 1988; Eddleston and Kellermanns, 2007).

\footnotetext{
${ }^{2}$ We also ran our analyses considering all different industries separately. Results remained substantially similar to those reported here. In line with previous studies (e.g. Chirico and Salvato, 2014), we report the results with the industry dummy variable to improve model fit.
} 


\section{Validity of the Scales}

We tested the measurement model in three steps. First, to assess the fit of our model, we used a chi-square statistic $\left(\chi^{2}\right)$ (i.e. the ratio between $\chi^{2}$ and the degree of freedom) lower than 3 (Bagozzi and Yi, 1988), the Bentler-Bonett normed fit index (BBNFI), the BentlerBonett non-normed fit index (BBNNFI), the comparative fit index (CFI), the incremental fit index (IFI), and a McDonald's fit index (MFI) greater than 0.90. Additionally, we investigated the root mean square error of approximation (RMSEA) for the models. An RMSEA value lower than 0.08 is suggested to indicate a good fit (e.g. Kline, 2005). The confirmatory factor analysis indicates an acceptable fit $(\mathrm{BBNFI}=0.88 ; \mathrm{BBNNFI}=0.99 ; \mathrm{CFI}$ $\left.=0.99 ; \mathrm{IFI}=0.99 ; \mathrm{MFI}=0.98 ; \mathrm{RMSEA}=0.019 ; \mathrm{S}-\mathrm{B} \chi^{2}(123)=130.49 ; \mathrm{p}=0.30\right)$.

In the second step, we checked that the standardised factor loadings of all items loaded significantly on their respective factors. The factor loadings ranged from 0.46 to 0.97 . All indicators were significant. The composite reliability $(\mathrm{CR})$ of the constructs ranged from 0.72 to 0.85 . The average variance extracted (AVE) of the constructs ranged from 0.57 to 0.73 . The Cronbach's $\alpha$ of the constructs ranged from 0.71 to 0.85 . These indicators exceeded their respective recommended threshold values of 0.40 (Ford et al., 1986), 0.70 (Nunnally and Bernstein, 1994), 0.70, and 0.50 (Fornell and Larcker, 1981). They thereby provide evidence of convergent validity and internal consistency (see Table 2).

In the third step, discriminant validity was assessed by comparing the squared correlation between two constructs with their respective AVEs (Fornell and Larcker, 1981). All the squared correlations were lower than the AVEs, indicating discriminant validity.

\section{--- Insert Table 2 about here ---}

\section{Results of the Structural Models}

Table 3 presents the descriptive statistics and correlations for all the variables analysed in this study. Table 4 presents the structural model results and statistics in different steps. As 
shown in Table 4, Hypotheses 1 and 2 are supported: both family and non-family SC are significantly and positively related to firm performance. Hypothesis 3 predicted that nonfamily SC would be a stronger determinant of firm performance than family SC. To test this hypothesis, we relied on the Akaike's (1987) information criterion (AIC) and Bozdogan's (1987) consistent version of AIC (CAIC) (non-nested hypothesis test; see Clarke, 2001). For Model 1 (Family SC $\rightarrow$ Performance) and Model 2 (Non-family SC $\rightarrow$ Performance), the AICs are -111.33 and -113.21 , respectively, and the CAICs are -625.62 and -627.50 , respectively. First, the model that produces the minimum AIC or CAIC is considered to be more parsimonious (Chou and Bentler, 1996). Second, the $\mathrm{R}^{2}$ is higher for non-family SC (Model 2, $\mathrm{R}^{2}=0.35$ ) than for family SC (Model 1, $\mathrm{R}^{2}=0.32$ ) (Smith et al., 1993). Finally, following Fortune and Mitchell (2012), when regressing firm performance on both family and non-family SC (Model 3), the effect of non-family SC on firm performance (unstandardised loading $=0.95 ;$ standardised loading $=0.30 ; \mathrm{p}<0.01)$ is stronger than that of family SC (unstandardised loading $=0.57 ;$ standardised loading $=0.24 ; \mathrm{p}<0.01)($ Table 4, Model 3). We can thus conclude that Hypothesis 3 is supported.

\section{--- Insert Table 3 about here ---}

\section{Test of Mediation}

Hypothesis 4 predicted a positive relationship between family SC and firm performance, mediated by non-family SC. This hypothesis was tested following the mediation guidelines outlined by MacKinnon et al. (2002). This required establishing a relationship between the independent variable (family SC), the mediator (non-family SC), and the dependent variable (firm performance). We calculated the direct and indirect effects using SEM (James et al., 2006) and analysed whether the relationships between these variables were significant after the introduction of the mediator. The analysis fully confirms the partial 
mediation of non-family SC (Table 4, Model 5). Second, we conducted the Sobel test (Sobel, 1982), which confirms that the mediation effect is significant $(\mathrm{z}=2.03 ; \mathrm{p}<0.05)$.

\section{--- Insert Table 4 about here ---}

We also developed a nested model (Anderson and Gerbing, 1988; Eddleston and Kellermanns, 2007) and performed the nested model comparisons test (e.g. Hu and Bentler, 1995). As shown in Table 5, we compared the fit of the fully mediated model (Model 4) with that of a partially mediated model (Model 5). The $\chi 2$ difference tests of the partially mediated model led to improved fit over the fully mediated model $\left(\chi^{2}\right.$ difference $[129-128]=140.69$ $136.32=4.37 ; \mathrm{p}<0.05)$. The path between family SC and firm performance, in which nonfamily SC partially mediates this relationship, is significant. This result suggests that the model with the best fit is the one in which non-family SC partially mediates the relationship between family SC and firm performance (Table 5 and Figure 1).

\section{--- Insert Table 5 about here ---}

To obtain further evidence of partial mediation, we used bootstrapping (Shrout and Bolger, 2002) ${ }^{3}$ to construct a confidence interval for the mediating role of non-family SC. Based on our sample, we conducted the bootstrapping procedure with 5,000 random samples using replacements from the full sample and a 0.95 confidence interval. Because the confidence interval excluded zero, the results confirm that partial mediation was present (Shrout and Bolger, 2002). Therefore, we can conclude that Hypothesis 4 is fully supported.

\section{--- Insert Figure 1 about here ---}

\section{DISCUSSION}

In our study, we focus on the importance of SC in family firms by extending the application to both family and non-family groups, while stressing the critical role of nonfamily SC and providing important insights for creating viable human resource strategies. By

\footnotetext{
${ }^{3}$ This approach is a nonparametric resampling procedure that does not impose the assumption of normality on the sampling distribution (Preacher and Hayes, 2008).
} 
doing so, we have developed a model depicting the structural, relational, and cognitive dimensions of both family and non-family SC and the effects of both on firm performance. Family groups have received much attention in the strategy, entrepreneurship, and family business research (Chirico and Salvato, 2014; Salvato and Melin, 2008; Sirmon and Hitt, 2003). However, in contrast, there is a dearth of studies focusing on the non-family group. We follow the calls by some scholars (e.g. McCollom, 1992; Ram, 2001) to consider the nonfamily group as an additional level of analysis when investigating family firm SC (e.g. McCollom, 1992; Ng and Roberts, 2007; Ram, 2001; Sonfield and Lussier, 2009b). Indeed, to capture the scope and importance of SC within family firms, it is pertinent to diverge from the tendency of most of the research to focus only on the family group. It is problematic and misleading to neglect the presence of non-family members and their relationships when looking at family firm performance outcomes (e.g. Astrachan and Zellweger, 2008; Sharma and Irving, 2005).

Specifically, building on SC theory and family firm arguments, we found that both family and non-family SC have positive effects on firm performance. This is not only a product of (blood) ties but also probably a reflection of the unique family business culture created by combining family and non-family members (e.g. Ram and Holliday, 1993). Interestingly, we also found that the positive effect of non-family SC on family firm performance is stronger than the effect of family SC. Finally, another insight is that nonfamily SC positively mediates the family SC/firm performance relationship. The hypotheses were tested using survey data collected through telephone interviews with 172 family firms, with responses from one family member and one non-family member per firm, both of whom have managerial functions. In the sections below, we examine interesting avenues of exploration based on the theoretical and practical implications of these findings for 
developing a broader understanding of both family and non-family SC in relation to firm performance.

\section{Theoretical Implications}

Important contributions emerge from our study. First, our study supports the theoretical assertions in the SC literature regarding the importance of social interactions and group members' relationships and understanding (Fukuyama, 1995; Inkpen and Tsang, 2005; Leana and Van Buren, 1999; Pearson et al., 2008; Tsai and Ghoshal, 1998). Our findings confirm that family and non-family members who spend time with each other and have close contact, trust and trustworthiness, and common ambitions and objectives contribute to increased firm performance, which indicates that one strategic advantage for family firms lies in building strong SC relationships. This provides an important contribution, as there is a need to develop a better understanding of what organisations should 'actually do' and 'actually behave' in order to create human resource management (HRM) practices that facilitate socialisation among firm members (e.g. Adler and Kwon, 2002; Bolino et al., 2002; Kostova and Roth, 2003; Nahapiet and Ghoshal, 1998).

Relatedly, although other scholars have identified SC theory as being particularly relevant to the study of family firms (e.g. Arregle et al., 2007; Hoffman et al., 2006; Pearson et al., 2008), to the best of our knowledge, this is the first study to empirically test the effects of both family and non-family SC on firm performance. Our focus on both family and nonfamily groups enables us to provide a more fine-grained understanding of the different forms of family firm SC. In line with the arguments of McCollom (1992), Sharma and Irving (2005), and Stewart and Hitt (2012), we have shown that two forms of SC exist in family firms and, as such, influence family firm outcomes. Family SC (with its three related dimensions - structural, relational, and cognitive) has a positive relationship with performance because it encourages a culture of long-term goal orientation, trust, and mutual 
understanding. Further, non-family SC (with its three related dimensions - structural, relational, and cognitive) also has a positive effect on firm performance because of the diversity, professionalism, and innovative behaviours of members of the non-family group.

Second, our work demonstrates that non-family SC has a stronger effect than family $\mathrm{SC}$ on firm performance because the diversity and professionalism of non-family members are important contributors to the success of family firms (Astrachan and Zellweger, 2008; Salvato et al., 2010; Sharma and Irving, 2005). Further, as Ng and Roberts (2007) found, nonfamily members implement corrective actions to mitigate potential tensions among family members. Forms of both strong and weak ties may thus be beneficial for a family organisation (Burt, 1992; Granovetter, 1973). Our theory and findings complement recent studies emphasising that family firms outperform non-family firms when non-family members are present (e.g. Savolainen and Kansikas, 2013; Sonfield and Lussier, 2009a). They also shed some light on previous work that offered mixed results regarding the effects of SC on firm performance, ranging from a positive relationship (e.g. Sorenson et al., 2009; Uhlaner et al., 2007) to a negative relationship (Edelman et al., 2004; Gargiulo and Benassi, 1999). Our work suggests that it is important to examine the different types of relationships and potential family ties among actors, rather than simply the strength of the relationships.

Third, we show that non-family SC plays a mediating role in the relationships between family SC and firm performance. Family firms with high family SC that recognise, value, and contribute to non-family SC achieve high-level performance. The simultaneous consideration of these factors provides a better understanding and a more pronounced view of how family firms differ in their use of family and non-family groups to realise positive outcomes. As such, while previous studies have analysed the SC construct at different levels (e.g. Bolino et al., 2002; Leana and Van Buren, 1999) and suggested that SC is homogeneous and independent of other social groups within an organisation, we have demonstrated the 
coexistence of two forms of SC in family firms, and the importance and predominant role of non-family SC and its dimensions.

Fourth, our study contributes to the literature on cultural competence ${ }^{4}$. Previously, scholars have noted the important role of family-influenced organisational culture for successfully managing family firms (e.g. Astrachan et al., 2002b; Dyer, 1986; Hall et al., 2001); family values and norms permeate the whole organisation and encourage the spread of cultural patterns at various levels (Dyer, 1988; Hall et al., 2001). Interestingly, Hall and Nordqvist (2008: 58) proposed an extension of the meaning of professional management to include what they call 'cultural competence, defined as an understanding of the family's goals and meanings of being in business, that is, the values and norms underlying the reason for the family to be in business'. Our study suggests that non-family members, who usually fulfil the pre-requisites of professionalisation through formal competence indicators such as education and prior experience (Astrachan et al., 2002a; Hall and Nordqvist, 2008), specifically portray cultural competence. Through reciprocal role taking, interaction, and communication (see Hall and Nordqvist, 2008), they are in fact better able to understand, bridge, and align the family and business goals, thus fostering a collective professional work environment which contributes to positive firm outcomes (Hall and Nordqvist, 2008; Hall et al., 2001).

Fifth, recent family firm research has explored family firm heterogeneity - not all family firms have the same behaviours and achieve the same results - by focusing on family groups only (Melin and Nordqvist, 2007; Nordqvist et al., 2014). While sharing several characteristics, family firms are not homogeneous in all aspects. Family firms vary significantly in the ways they pursue their objectives. For example, family firms differ in terms of generation in control, generational involvement (Kellermanns and Eddleston, 2006), family members' openness to change and participation in shaping the firm's strategy (e.g.

\footnotetext{
${ }^{4}$ We thank one of our anonymous reviewers for this insightful suggestion.
} 
Chirico and Nordqvist, 2010; Eddleston and Kellermanns, 2007). Our study also shows that family firm diversity is partially a by-product of the heterogeneous makeup of family and non-family members.

Finally, given that, like many others, the family firm is an organisational archetype characterised by a dominant social group (Foreman and Whetten, 2002), many of the characteristics of the relationships that occur in a family firm context could be generalised to other organisations. In this sense, our study has the potential to help scholars and practitioners to better understand SC and performance within other organisational forms characterised by strong social structures.

\section{Practical Implications}

Our study also offers important insights to managers. A conceptual articulation supported by empirical data that addresses the extent to which different forms of SC affect firm performance is beneficial to managers as a way to understand family firm behaviours. Our results offer practitioners a tool to better understand the social processes leading to higher performance levels. Managers should carefully assess the benefits of strong and collaborative relationships within and among the family group and the non-family group in family firms (Craig and Moores, 2010). This is relevant given that existing studies indicate that family firms often hire non-family executives (e.g. a non-family CEO) to increase performance outcomes (Salvato et al., 2010). Non-family members are often capable of achieving positive firm outcomes through their knowledge, experience, and personal social networks beyond the family (Mitchell et al., 2003; Sharma, 2004), and they can also potentially reduce the tensions between family members ( $\mathrm{Ng}$ and Roberts, 2007). As such, better integration of non-family members into the business is relevant to maximising performance. For this reason, the drivers and elements of non-family SC must be well managed and understood.

\section{Limitations and Future Research}


Before formally concluding our study, we note a few caveats, which also serve as future research avenues. First, we do not directly measure some constructs, such as knowledge exchange and members' professionalism, but instead argue that they play a central role in explaining the hypothesised relationships. Second, our research is based on Spanish non-listed family firms, which may limit the generalisability of our results. In Spain, great importance is placed on family relationships (Steier, 2009), and family unity and harmony are much more highly valued than in other countries (e.g. the United States) (Poza, 1995). Thus, it would be interesting to compare this context to other, more individualistic settings in which the individual's importance and personal achievements are placed above the group's interest. Third, although we control for the percentage of family members on the TMT (an important proxy for family involvement; see Chirico and Bau, 2014) and the family generation in control (see Ling and Kellermanns, 2010), other family influence variables (e.g. generational involvement, presence of a family CEO) might affect our results. Fourth, the cross-sectional design of the study precludes the ability to make statements about causal relationships. Therefore, longitudinal and more process-specific studies will be required to test causality. It would be valuable to test the effect of the combination or interaction of family and non-family SC on firm performance or other outcomes over time.

\section{Concluding Remarks}

Given that family-controlled firms are the predominant organisational form worldwide (e.g. Acquaah, 2011; Cesinger et al., 2014), more attention needs to be given to how family group and non-family group relationships are built within this type of organisation. More broadly, both family SC and non-family SC should take a central place in our understanding of firm performance. We are confident that our study will stimulate further work on the different forms of SC in a context (i.e. the family firm) in which social factors are predominant. 


\section{References}

Acquaah M (2011) Utilization and value of social networking relationships in family and nonfamily firms in an African transition economy. European Management Journal 29(5): 347-61.

Adler PS and Kwon S (2002) Social capital: Prospects for a new concept. Academy of Management Review 27(1): 17-40.

Akaike H (1987) Factor analysis and AIC. Psychometrika 52(3): 317-32.

Alavifar A, Karimimalayer M and Anuar MK (2012) Structural equation modeling vs multiple regression. Engineering Science and Technology: An International Journal 2(2): 326-9.

Allen MP and Panian SK (1982) Power, performance, and succession in large corporation. Administrative Science Quartely 27(1): 538-47.

Anderson JC and Gerbing DW (1988) Structural equation modelling in practice: A review and recommended two-step approach. Psychological Bulletin 103(3): 411-23.

Arregle JL, Hitt MA, Sirmon DG and Very P (2007) The development of organizational social capital: Attributes of family firms. Journal of Management Studies 44(1): 73-95.

Astrachan JH, Keyt AD, Lane PJ and Yarmalouk D (2002a) Non-family CEOs in the family business: Connecting family values to business success. In: Koiranen $\mathrm{M}$ and Karlsson $\mathrm{N}$ (eds) Proceedings from the 2002 Family Business Network Research Forum. Helsinki: Tampere-Paino.

Astrachan JH, Klein SB and Smyrnios KX (2002b) The F-PEC scale of family influence: A proposal for solving family business definition problem. Family Business Review 15(1): 45-58.

Astrachan JH and Zellweger T (2008) Performance of family firms: A literature review and guidance for future research. Journal of Small and Medium-sized Enterprise and Entrepreneurship 56(1/2): 1-22.

Bagozzi RP and Yi Y (1988) On the evaluation of structural equation model. Journal of the Academy of Marketing Science 16(1): 74-94.

Barney JB and Hansen MH (1994) Trustworthiness as a source of competitive advantage. Strategic Management Journal 15(S1): 175-90.

Basco R (2013) The family's effect on family firm performance: A model testing the demographic and essence approaches. Journal of Family Business Strategy 4(1): 42-66.

Bentler PM (1995) EQS Structural Equations Program Manual. Encino, CA: Multivariate Software.

Boland RJ and Tenkasi RV (1995) Perspective making and perspective taking in communities of knowing. Organization Science 6(4): 350-72.

Bolino MC, Turnley WH and Bloodgood JM (2002) Citizenship behavior and the creation of social capital in organizations. Academy of Management Review 27(4): 505-22.

Bozdogan H (1987) Model selection and Akaike's information criterion (AIC): The general theory and its analytical extension. Psychometrika 52(3): 345-70.

Bubolz MM (2001) Family as source, user, and builder of social capital. Journal of SocioEconomics 30(2): 129-31. 
Burt RS (1992) Structural Holes: The Social Structure of Competition. Cambridge: Harvard University Press.

Carr JC, Cole MS, Kirk-Ring J and Blettner DP (2011) A measure of variations in internal social capital among family firms. Entrepreneurship Theory and Practice 35(6): 1207-27.

Casanueva-Rocha C, Castro-Abancéns I and Galan-González JL (2010) Social capital and innovation in industry clusters. Revista Europea de Dirección y Economía de la Empresa 19(4): 37-58.

Casson M and Giusta MD (2007) Entrepreneurship and social capital: Analysing the impact of social networks on entrepreneurial activity from a rational action perspective. International Small Business Journal 25(3): 220-44.

Cesinger B, Bouncken R, Fredrich V and Kraus S (2014) The alchemy of family enterprises' internationalisation: dexterous movers or prodigal laggards? European Journal of International Management 8(6): 671-96.

Chirico F and Bau M (2014) Is the family an 'Asset' or 'Liability' for firm performance? The moderating role of environmental dynamism. Journal of Small Business Management 52(2): 210-25.

Chirico F, Ireland D and Sirmon DG (2011a) Franchising and the family firm: Creating unique sources of advantage through "familiness". Entrepreneurship Theory and Practice 35(3): 483-501.

Chirico F and Nordqvist M (2010) Dynamic capabilities and trans-generational value creation in family firms: The role of organizational culture. International Small Business Journal 28(5): 487-504.

Chirico F and Salvato C (2008) Knowledge integration and dynamic organizational adaptation in family firms. Family Business Review 21(2): 169-81.

Chirico F, Sirmon DG, Sciascia S and Mazzola P (2011b) Resource orchestration in family firms: Investigating how entrepreneurial orientation, generational involvement, and participative strategy affect performance. Strategic Entrepreneurship Journal 5(4): 30726.

Chirico F and Salvato C (2014) Knowledge internalization and product development in family firms: When relational and affective factors matters. Entrepreneurship Theory and Practice, http://dx.doi.org/10.1111/etap.12114.

Chou C, Bentler PM and Satorra A (1991) Scaled test statistics and robust standard errors for nonnormal data in covariance structure analysis. British Journal of Mathematical and Statistical Psychology 44(2): 347-57.

Chou CP and Bentler PM (1996) Application of AIC to Wald and Lagrange multiplier tests in covariance structure analysis. Multivariate Behavioral Research 31(3): 351-70.

Chua JH, Chrisman JJ and Sharma P (2003) Succession and non succession concern of family firms and agency relationships with nonfamily managers. Family Business Review 16(2): 89-108.

Chua JH, Chrisman JJ, Steier LP and Rau SB (2012) Sources of heterogeneity in family firms: An introduction. Entrepreneurship Theory and Practice 36(6): 1103-13.

Clarke KA (2001) Testing non-nested models of international relations: Reevaluating realism. Journal of Political Science 45(3): 724-44. 
Cohen WM and Levinthal DA (1990) Absorptive capacity: A new perspective on learning and innovation. Administrative Science Quartely 35(1): 128-52.

Coleman JS (1990) Foundations of Social Theory. Cambridge: Harvard University Press.

Coleman JS (1988) Social capital in the creation of human capital. American Journal of Sociology 94(S): S95-S120.

Craig JB and Moores K (2010) Strategically aligning family and business systems using the balance scorecard. Journal of Family Business Strategy 1(2): 78-87.

Cross R and Prusak L (2002) The people who make organizations go or stop. Harvard Business Review 80(6): 104-12.

Cuevas-Rodriguez G, Cabello-Medina C and Carmona-Lavado A (2014) Internal and external social capital for radical product innovation: Do they always work well together? British Journal of Management 25(2): 266-84.

Distelberg BJ (2008) Nonfamily employees. Family Business Alliance .

Dyer Jr. WG (1988) Culture and continuity in family firms. Family Business Review 1(1): 3750.

Dyer Jr. WG (1986) Cultural Change in Family Firms: Anticipating and Managing Business and Family Transitions. San Francisco: Jossey-Bass.

Eddleston KA (2012) The family as an internal and external resource of the firm: The importance of building family-firm identity. In: Sorenson RL (ed.) Family Business and Social Capital. Cheltenham: Edward Elgar, 186-97.

Eddleston KA and Kellermanns FW (2007) Destructive and productive family relationships: A stewardship theory perspective. Journal of Business Venturing 22(4): 54565.

Edelman L, Bresnen M, Newell S, Scarbrough H and Swan J (2004) The benefits and pitfalls of social capital: Empirical evidence from two organizations in the United Kingdom. British Journal of Management 15(S1): S59-69.

European Group of Family Enterprises (GEEF) (2009), Final report of the expert group. Overview of family-business-relevant issues: Research, networks, policy measures and existing studies. European Commision. , 1-33.

Ford JC, McCallum RC and Tait M (1986) The application of exploratory factor analysis in applied psychology: A critical review and analysis. Personnel Psychology 39(2): 291-314.

Foreman P and Whetten DA (2002) Members' identification with multiple-identity organizations. Organization Science 13(6): 618-35.

Fornell C and Larcker DF (1981) Evaluating structural equations models with unobservable variables and measurement error. Journal of Marketing Research 18(1): 39-50.

Fortune A and Mitchell W (2012) Unpacking firm exit at the firm and industry levels: The adaptation and selection of firm capabilities. Strategic Management Journal 33(7): 794819.

Fukuyama F (1995) Trust. New York: Free Press.

Gargiulo M and Benassi M (1999) The dark side of social capital. In: Leenders R and Gabbay S (eds) Corporate Social Capital and Liability. Boston: Kluwer, 298-322. 
Gomez-Mejia LR, Haynes KT, Nunez-Nickel M, Jacobson KJ and Monayo-Fuentes J (2007) Socioemotional wealth and business risks in family-controlled firms: Evidence from Spanish olive oil mills. Administrative Science Quartely 52(1): 106-37.

Gomez-Mejia LR, Larraza-Kintana M and Makri M (2003) The determinants of executive compensation in family-controlled public corporations. Academy of Management Journal 46(2): 226-37.

Gomez-Mejia LR, Nunez-Nickel M and Gutierrez I (2001) The role of family ties in agengy contracts. Academy of Management Journal 44(1): 81-95.

Granovetter MS (1992) Problems of explanation in economic sociology. In: Nohria N and Eccles RG (eds) Networks and Organizations: Structure, Form, and Action. Boston: Harvard Business School Press, 25-56.

Granovetter MS (1985) Economic action and social structure: The problem of embeddedness. American Journal of Sociology 91(3): 481-510.

Granovetter MS (1973) Strength of weak ties. American Sociological Review 78(6): 1360-80.

Habbershon TG and Williams ML (1999) A resource-based framework for assessing the strategic advantages of family firms. Family Business Review 12(1): 1-25.

Habbershon TG, Williams ML and MacMillan IC (2006) A unified systems perspective of family firm performance. In: Poutziouris PZ, Smyrnios KX and Klein SB (eds) Handbook of Research on Family Business. United Kingdom: Edward Elgar, 67-79.

Hall A (2003) Strategising in the Context of Genuine Relations. an Interpretative Study of Strategic Renewal through Family Interactions. Jönköping: Jönköping International Business School Ltd.

Hall A, Melin L and Nordqvist M (2001) Entrepreneurship as radical change in the family business: Exploring the role of cultural patterns. Family Business Review 14(3): 193-208.

Hall A and Nordqvist M (2008) Professional management in family businesses: Toward an extended understanding. Family Business Review 21(1): 51-69.

Hoffman J, Hoelscher M and Sorenson RL (2006) Achieving sustained competitive advantage: A family capital theory. Family Business Review 19(2): 135-45.

Hu LT and Bentler PM (1995) Evaluating model fit. In: Hoyle RH (ed.) Structural Equation Modeling. Concepts, Issues, and Applications. London: Sage, 76-99.

Hu LT, Bentler PM and Kano Y (1992) Can test statistics in covariance structure analysis be trusted? Psychological Bulletin 112(2): 351-62.

Iacobucci D, Saldanha N and Deng X (2007) A meditation on mediation: Evidence that structural equations models perform better than regressions. Journal of Consumer Psychology 17(2): 140-54.

Inkpen A and Tsang EW (2005) Social capital, networks, and knowledge transfer. Academy of Management Review 30(1): 146-65.

James LR, Mulaik SA and Brett JM (2006) A tale of two methods. Organizational Research Methods 9(2): 233-44.

Kellermanns FW and Eddleston KA (2006) Corporate entrepreneurship in family firms: A family perspective. Entrepreneurship Theory and Practice 30(6): 809-30. 
Kline RB (2005) Principles and Practice of Structural Equation Modeling, 2nd edn. New York: Guilford.

Kostova T and Roth K (2003) Social capital in multinational corporations and micro-macro model of its formation. Academy of Management Review 28(2): 297-317.

Kramer RM, Brewer MB and Hanna BA (1996) Collective trust and collective action: The decision to trust as a social decision. In: Kramer RM and Tyler TR (eds) Trust in Organizations: Frontiers of Theory and Research. Thousand Oaks: Sage, 357-89.

Law KS, Wong CS and Mobley WH (1998) Toward a taxonomy of multidimensional constructs. Academy of Management Review 23(4): 741-55.

Leana CR and Van Buren HJ (1999) Organizational social capital and employment practices. Academy of Management Review 24(3): 538-55.

Ling Y and Kellermanns FW (2010) The effects of family firm specific diversity: The moderating role of information exchange frequency. Journal of Management Studies 47(2): 332-44.

Lumpkin GT and Dess GG (1996) Clarifying the entrepreneurial orientation construct and linking it to performance. Journal of Management Review 21(1): 135-72.

Mackinnon DP, Lockwood CM, Hoffman JM, West SG and Sheets V (2002) A comparison of methods to test mediation and other intervening variable effects. Psychol Methods 7(1): 83.

McCollom M (1992) Organizational stories in family-owned business. Family Business Review 5(1): 3-23.

McConaughy DL (2000) Family CEOs vs. nonfamily CEOs in the family-controlled firm: An examination of the level and sensitivity of pay to performance. Family Business Review 13(2): $121-31$.

Melin L and Nordqvist M (2007) The reflexive dynamics of institutionalization: The case of the family business. Strategic Organization 5(3): 321-33.

Miller D and Le Breton-Miller I (2005) Managing for the Long Run: Lessons in Competitive Advantage from Great Family Businesses. Boston: Harvard Business School Press.

Miller D, Le Breton-Miller I, Minichilli A, Corbetta G and Pittino D (2014) When do nonfamily CEOs outperform in family firms? Agency and behavioural agency perspectives. Journal of Management Studies 51(4): 547-72.

Miller D, Lee J, Chang S and Le Breton-Miller I (2009) Filling the institutional void: The social behavior and performance of family vs. non-family technology firms in emerging markets. Journal of International Business Studies 40(5): 802-17.

Mitchell RK, Morse EA and Sharma P (2003) The transacting cognitions of nonfamily employees in the family businesses setting. Journal of Business Venturing 18(4): 533-51.

Nahapiet J and Ghoshal S (1998) Social capital, intellectual capital, and the organizational advantage. Academy of Management Review 23(2): 242-66.

Ng W and Roberts J (2007) 'Helping the family': The mediating role of outside directors in ethnic Chinese family firms. Human Relations 60(2): 285-314.

Nohria N (1992) Information and research in the creation of new business ventures: The case of 128 venture group. In: Nohria N and Eccles RG (eds) Networks and Organizations: Structure, Form and Action. Boston: Harvard Business School Press, 240-61. 
Nordqvist M, Sharma P and Chirico F (2014) Family firm heterogeneity and governance: A configuration approach. Journal of Small Business Management 52(2): 192-209.

Nunnally JC and Bernstein IH (1994) Psychometric Theory, 3rd edn. New York: McGrawHill.

Oh H, Labianca G and Chung MH (2006) A multilevel model of group social capital. Academy of Management Review 31(3): 569-82.

Pearson AW and Carr JC (2012) The central role of trust in family firm social capital. In: Sorenson RL (ed.) Family Business and Social Capital. Cheltenham: Edward Elgar, 33-44.

Pearson AW, Carr JC and Shaw JC (2008) Toward a theory of familiness: A social capital perspective. Entrepreneurship Theory and Practice 32(6): 949-69.

Perez-Gonzalez F (2006) Inherited control and firm performance. American Economic Review 96(5): 1559-88.

Portes A (1998) Social Capital: Its origins and applications in modern sociology. Annual Review of Sociology 241-24.

Poza EJ (1995) A La Sombra Del Roble. La Empresa Familiar y Su Continuidad (in the Shadow of the Oak: Continuity in the Family-Owned Business). Cleveland OH: Editorial Universitaria para la Empresa Familiar.

Preacher KJ and Hayes AF (2008) Asymptotic and resampling strategies for assessing and comparing indirect effects in multiple mediator models. Behavior Research Methods 4(3): 879-89.

Putnam RD (1993) The prosperous community: Social capital and public life. American Prospect 4(13): 35-42.

Ram M (2001) Family dynamics in a small consultancy firm: A case study. Human Relations 54(4): 395-418.

Ram M and Holliday R (1993) Relative merits: Family culture and kinship in small firms. Sociology 27(4): 629-48.

Redding SG (1990) The Spirit of Chinese Capitalism. Berlin: Walter de Gruyter.

Salvato C, Chirico F and Sharma P (2010) A farewell to the business: Championing exit and continuity in entrepreneurial family firms. Entrepreneurship \& Regional Development: An International Journal 22(3-4): 321-48.

Salvato C and Melin L (2008) Creating value across generations in family-controlled businesses: The role of family social capital. Family Business Review 21(3): 259-76.

Sanchez-Famoso V, Maseda A and Iturralde T (2014) The role of internal social capital in organizational innovation. An empirical study of family firms. European Management Journal 32(6): 950-62.

Sanchez-Famoso V, Maseda A and Iturralde T (2013) Relationship between family and nonfamily social capital: The case of Spanish family firms. Revista Europea de Dirección y Economía de la Empresa 22(4): 177-85.

Satorra A and Bentler PM (1988) Scaling Corrections for Chi-Square Statistics in Covariance Structure Analysis. Proceedings of the Business and Economic Sections. Alexandria, VA: American Statistical Association. 
Savolainen S and Kansikas J (2013) Non-family employees in small family business succession: The case of psychological ownership. World Review of Entrepreneurship, Management and Sustainable Development 9(1): 64-81.

Sharma P (2008) Commentary: Familiness: Capital stocks and flows between family and business. Entrepreneurship Theory and Practice 32(6): 971-7.

Sharma P (2004) An overview of the field of family business studies: Current status and directions for the future. Family Business Review 17(1): 1-36.

Sharma P and Irving PG (2005) Four bases of family business successor commitment: Antecedents and consequences. Entrepreneurship Theory and Practice 29(1): 13-33.

Shrout PE and Bolger N (2002) Mediation in experimental and nonexperimental studies: New procedures and recommendations. Psychological Methods 7(4): 422-45.

Sirmon DG, Arregle JL, Hitt MA and Webb JW (2008) The role of family influence in firms' strategic response to competitive threat. Entrepreneurship Theory and Practice 32(6): 979-98.

Sirmon DG and Hitt MA (2003) Managing resources: Linking unique resources, management, and wealth creation in family firms. Entrepreneurship Theory and Practice 27(4): 339-58.

Smith CA, Haynes KN, Lazarus RS and Pope LK (1993) In search of the "hot" cognitions: Attributions, appraisals, and their relation to emotion. Journal of Personality and Social Psychology 65(5): 916-29.

Sobel ME (1982) Asymptotic confidence intervals for indirect effects in structural equation models. In: Leinhardt S (ed.) Sociological Methodology. Washington: American Sociological Association, 290-312.

Sonfield MC and Lussier RN (2009a) Family-member and non-family-member managers in family businesses. Journal of Small Business and Enterprise Development 16(2): 196-209.

Sonfield MC and Lussier RN (2009b) Non-family-members in the family business management team: A multinational investigation. International Entrepreneurship and Management Journal 5(4): 395-415.

Sorenson RL (2012) Social capital and family business. In: Sorenson RL (ed.) Family Business and Social Capital. Cheltenham: Edward Elgar, 1-30.

Sorenson RL and Bierman L (2009) Family capital, family business and free enterprise. Family Business Review 22(3): 193-5.

Sorenson RL, Goodpaster KE, Hedberg PR and Yu A (2009) The family point of view, family social capital, and firm performance: An exploratory test. Family Business Review 22(3): 239-53.

Spanish Family Enterprise Institute (2009) The Family Business. Barcelona: Instituto de Empresa Familiar.

Spector PE (1994) Using self-report questionnaires in OB research: A comment on the use of controversial method. Journal of Organizational Behavior 15(5): 385-92.

Stam W, Arzlanian S and Elfring T (2014) Social capital of entrepreneurs and small firm performance: A meta-analysis of contextual and methodological moderators. Journal of Business Venturing 29(1): 152-73.

Steenkamp J and Baumgartner H (2000) On the use of structural equation models for marketing modelling. International Journal of Research in Marketing 17(2-3): 195-202. 
Steier LP (2009) Where do new firms come from? Households, family capital, ethnicity, and the welfare mix. Family Business Review 22(3): 273-8.

Stewart A (2003) Help one another, use one another: Toward an anthropology of family business. Entrepreneurship Theory and Practice 27(4): 383-96.

Stewart A and Hitt MA (2012) Why can't a family business be more like a nonfamily business? Modes of professionalization in family firms. Family Business Review 25(1): 58-86.

Tsai W and Ghoshal S (1998) Social capital and value creation: The role of intrafirm networks. Academy of Management Journal 41(4): 464-76.

Uhlaner LM, Floren RH and Geerlings JR (2007) Owner commitment and relational governance in the privately-held firm: An empirical study. Small Business Economics 29(3): 275-93.

Uhlaner LM, Kellermanns FW, Eddleston KA and Hoy F (2012) The entrepreneuring family: A new paradigm for family business research. Small Business Economics 38(1): 1-11.

Vallejo-Martos MC (2009) The effects of commitment of non-family employees of family firms from the perspective of stewardship theory. Journal of Business Ethics 87(3): 37990.

Vandekerkhof P, Steijvers T, Hendriks W and Voordeckers W (2014) The effect of organizational characteristics on the appointment of nonfamily managers in private family firms: The moderating role of socioemotional wealth. Family Business Review, http://dx.doi.org/10.1177/0894486513514274.

Venkatraman N and Ramanujam V (1987) Measurement of business economic performance: An examination of method convergence. Journal of Management 13(1): 109-22.

Venkatraman N and Ramanujam V (1986) Measurement of business performance in strategy research: A comparison of approaches. Academy of Management Review 11(4): 801-14.

Villena VH, Revilla E and Choi TY (2011) The dark side of buyer-supplier relationships: A social capital perspective. Journal of Operations Management 29(6): 561-76.

Watson WE, Johnson L and Merritt D (1998) Team orientation, self-orientation, and diversity in task groups. Group \& Organization Management 23(2): 161-88.

Westlund H and Bolton R (2003) Local social capital and entrepreneurship. Small Business Economics 21(2): 77-113.

Zahra SA, Hayton JC and Salvato C (2004) Entrepreneurship in family vs. non-family firms: A resource-based analysis of the effect of organizational culture. Entrepreneurship Theory and Practice 28(4): 363-81.

Zahra SA and Nielsen AP (2002) Sources for capabilities, integration and technology commercialization. Strategic Management Journal 23(5): 377-98.

Zahra SA (2010) Harvesting family firms' organizational social capital: A relational perspective. Journal of Management Studies 47(2): 345-66. 
TABLE 1: Sample Characteristics

\begin{tabular}{|c|c|}
\hline \multicolumn{2}{|l|}{ Composition of questionnaire respondents } \\
\hline TOTAL QUESTIONNAIRES USED & 344 \\
\hline Family Member Respondents & 172 \\
\hline CEOs & 88 \\
\hline Managers & 84 \\
\hline Non-Family Member Respondents & 172 \\
\hline CEOs & 16 \\
\hline Managers & 156 \\
\hline Sampled Companies (All Family Firms) & \multirow{2}{*}{$\begin{array}{l}\text { Number of Firms } \\
\text { (Percentage) }\end{array}$} \\
\hline Age (years) & \\
\hline Less than 10 & $10(6 \%)$ \\
\hline $10-25$ & $73(42 \%)$ \\
\hline $26-50$ & $75(44 \%)$ \\
\hline More than 50 & $14(8 \%)$ \\
\hline \multicolumn{2}{|l|}{ Firm Size (number of employees) } \\
\hline $10-50$ & $40(23 \%)$ \\
\hline $51-250$ & $123(72 \%)$ \\
\hline More than 250 & $9(5 \%)$ \\
\hline \multicolumn{2}{|l|}{ Generational Involvement } \\
\hline Only one generation & $96 \quad(56 \%)$ \\
\hline Two generations & $69 \quad(40 \%)$ \\
\hline Three or more generations & $7 \quad(4 \%)$ \\
\hline \multicolumn{2}{|l|}{ Family Firm Generation } \\
\hline First Generation & $63(37 \%)$ \\
\hline Second Generation & $71(41 \%)$ \\
\hline Third Generation & $20(12 \%)$ \\
\hline Fourth Generation & $14(8 \%)$ \\
\hline Fifth or Later Generation & $4(2 \%)$ \\
\hline \multicolumn{2}{|l|}{ Sector } \\
\hline Manufacturing Firms & $82(48 \%)$ \\
\hline Service Firms & $90(52 \%)$ \\
\hline
\end{tabular}


TABLE 2: Validation of the final measurement model (first and second-order reflective factors) - reliability and convergent validity

\begin{tabular}{|c|c|c|c|c|c|c|c|}
\hline & Constructs & Indicator & $\begin{array}{l}\text { Standardised } \\
\text { Loading }\end{array}$ & $\begin{array}{l}\text { Robust } \\
t \text {-value }\end{array}$ & $\mathbf{C A}$ & $\mathbf{C R}$ & AVE \\
\hline \multirow{6}{*}{ Family SC } & \multirow[t]{2}{*}{ F1. Family Structural Dimension } & Item 1 & $0.97 * * *$ & 4.70 & \multirow[t]{2}{*}{0.80} & \multirow[t]{2}{*}{0.82} & \multirow[t]{2}{*}{0.71} \\
\hline & & Item 2 & $0.68 * * *$ & 4.70 & & & \\
\hline & \multirow[t]{2}{*}{ F2. Family Relational Dimension } & Item 3 & $0.92 * * *$ & 8.03 & \multirow[t]{2}{*}{0.84} & \multirow[t]{2}{*}{0.85} & \multirow[t]{2}{*}{0.73} \\
\hline & & Item 4 & $0.79 * * *$ & 8.02 & & & \\
\hline & \multirow[t]{2}{*}{ F3. Family Cognitive Dimension } & Item 5 & $0.84 * * *$ & 8.68 & \multirow[t]{2}{*}{0.74} & \multirow[t]{2}{*}{0.75} & \multirow[t]{2}{*}{0.60} \\
\hline & & Item 6 & $0.70 * * *$ & 8.68 & & & \\
\hline \multirow{6}{*}{ Non-Family SC } & \multirow[t]{2}{*}{ F4. Non-Family Structural Dimension } & Item 7 & $0.81 * * *$ & 4.33 & \multirow[t]{2}{*}{0.71} & \multirow[t]{2}{*}{0.72} & \multirow[t]{2}{*}{0.56} \\
\hline & & Item 8 & $0.69 * * *$ & 4.33 & & & \\
\hline & \multirow[t]{2}{*}{ F5. Non-Family Relational Dimension } & Item 9 & $0.83 * * *$ & 8.03 & \multirow[t]{2}{*}{0.80} & \multirow[t]{2}{*}{0.80} & \multirow[t]{2}{*}{0.66} \\
\hline & & Item 10 & $0.80 * * *$ & 8.03 & & & \\
\hline & \multirow[t]{2}{*}{ F6. Non-Family Cognitive Dimension } & Item 11 & $0.84 * * *$ & 10.03 & \multirow[t]{2}{*}{0.85} & \multirow[t]{2}{*}{0.85} & \multirow[t]{2}{*}{0.73} \\
\hline & & Item 12 & $0.88 * * *$ & 10.03 & & & \\
\hline \multirow{2}{*}{ Performance } & \multirow[t]{2}{*}{ F7. Performance } & Item 13 & $0.87 * * *$ & 9.05 & \multirow[t]{2}{*}{0.83} & \multirow[t]{2}{*}{0.84} & \multirow[t]{2}{*}{0.72} \\
\hline & & Item 14 & $0.83 * * *$ & 9.16 & & & \\
\hline \multirow{3}{*}{ Family SC } & F1. Family Structural Dimension & & $0.47 * * *$ & 5.49 & \multirow[t]{3}{*}{0.78} & \multirow[t]{3}{*}{0.79} & 0.57 \\
\hline & F2. Family Relational Dimension & & $0.87 * * *$ & 8.51 & & & \\
\hline & F3. Family Cognitive Dimension & & $0.85 * * *$ & 7.50 & & & \\
\hline & F4. Non-Family Structural Dimension & & $0.46 * * *$ & 4.03 & 0.78 & 0.79 & 0.57 \\
\hline Non-Family SC & F5. Non-Family Relational Dimension & & $0.87 * * *$ & 7.50 & & & \\
\hline & F6. Non-Family Cognitive Dimension & & $0.86 * * *$ & 7.51 & & & \\
\hline & $\begin{array}{r}30) ; B B N F I=0.8 \\
R M S E A=0.019\end{array}$ & WLI & $\begin{array}{l}9 ; C F I=0 . \\
=0.77\end{array}$ & $I F I=$ & & & \\
\hline
\end{tabular}


TABLE 3: Descriptive statistics and correlations for all models

\begin{tabular}{|c|c|c|c|c|c|c|c|c|c|c|c|c|c|c|c|c|c|c|c|c|c|c|}
\hline & & Variable & Mean & s.d. & 1 & 2 & 3 & 4 & 5 & 6 & 7 & 8 & 9 & 10 & 11 & 12 & 13 & 14 & 15 & 16 & 17 & 18 \\
\hline 1 & \multirow{6}{*}{$\begin{array}{l}\text { Family } \\
\text { Members }\end{array}$} & Social Interactions: Time Spent & 3.56 & 1.16 & & & & & & & & & & & & & & & & & & \\
\hline 2 & & Social Interactions: Close Contact & 3.45 & 1.19 & 0.66 & & & & & & & & & & & & & & & & & \\
\hline 3 & & Trustworthiness: Reliability & 4.21 & 0.71 & 0.33 & 0.19 & & & & & & & & & & & & & & & & \\
\hline 4 & & Trustworthiness: Promise Keeping & 4.25 & 0.70 & 0.30 & 0.22 & 0.73 & & & & & & & & & & & & & & & \\
\hline 5 & & Shared Ambitions and Values & 4.24 & 0.78 & 0.33 & 0.24 & 0.57 & 0.54 & & & & & & & & & & & & & & \\
\hline 6 & & Shared Objectives and Mission & 4.13 & 0.87 & 0.21 & 0.24 & 0.49 & 0.44 & 0.59 & & & & & & & & & & & & & \\
\hline 7 & \multirow{6}{*}{$\begin{array}{l}\text { Non-Family } \\
\text { Members }\end{array}$} & Social Interactions: Time Spent & 3.52 & 1.07 & 0.22 & 0.24 & 0.17 & 0.19 & 0.19 & 0.15 & & & & & & & & & & & & \\
\hline 8 & & Social Interactions: Close Contact & 3.51 & 1.13 & 0.76 & 0.24 & 0.10 & 0.05 & 0.07 & 0.06 & 0.56 & & & & & & & & & & & \\
\hline 9 & & Trustworthiness: Reliability & 4.20 & 0.68 & 0.31 & 0.20 & 0.37 & 0.22 & 0.23 & 0.22 & 0.27 & 0.24 & & & & & & & & & & \\
\hline 10 & & Trustworthiness: Promise Keeping & 4.20 & 0.70 & 0.27 & 0.20 & 0.35 & 0.22 & 0.17 & 0.19 & 0.25 & 0.21 & 0.66 & & & & & & & & & \\
\hline 11 & & Shared Ambitions and Values & 4.09 & 0.85 & 0.31 & 0.28 & 0.31 & 0.26 & 0.29 & 0.28 & 0.30 & 0.30 & 0.50 & 0.51 & & & & & & & & \\
\hline 12 & & Shared Objectives and Mission & 4.17 & 0.89 & 0.32 & 0.25 & 0.30 & 0.21 & 0.33 & 0.29 & 0.26 & 0.22 & 0.56 & 0.53 & 0.73 & & & & & & & \\
\hline 13 & \multirow{2}{*}{$\begin{array}{l}\text { Family Firm } \\
\text { Performance }\end{array}$} & High Level of Profitability & 7.40 & 1.45 & 0.27 & 0.23 & 0.34 & 0.21 & 0.22 & 0.19 & 0.10 & 0.15 & 0.28 & 0.27 & 0.26 & 0.30 & & & & & & \\
\hline 14 & & High Financial Position & 7.21 & 1.62 & 0.24 & 0.12 & 0.35 & 0.20 & 0.19 & 0.21 & 0.08 & 0.16 & 0.29 & 0.32 & 0.28 & 0.29 & 0.72 & & & & & \\
\hline 15 & \multirow{5}{*}{$\begin{array}{l}\text { Control } \\
\text { Variables }\end{array}$} & Business Unit SIZE & 4.32 & 0.63 & 0.12 & 0.00 & 0.15 & 0.04 & 0.14 & 0.07 & 0.08 & 0.02 & -0.01 & 0.03 & 0.06 & 0.07 & 0.27 & 0.19 & & & & \\
\hline 16 & & Business Unit SECTOR & 0.48 & 0.50 & 0.10 & 0.03 & -0.07 & -0.01 & 0.04 & 0.07 & 0.02 & -0.08 & -0.01 & -0.02 & 0.01 & 0.06 & -0.04 & -0.07 & 0.21 & & & \\
\hline 17 & & Business Unit AGE & 3.13 & 0.58 & -0.01 & -0.07 & 0.06 & 0.02 & 0.07 & 0.05 & -0.05 & -0.12 & -0.10 & -0.02 & -0.04 & -0.12 & -0.08 & -0.09 & 0.33 & 0.06 & & \\
\hline 18 & & Family Members in TMT & 51.30 & 37.05 & -0.06 & -0.01 & -0.02 & 0.01 & -0.01 & 0.00 & 0.00 & 0.19 & -0.07 & -0.07 & -0.08 & 0.00 & -0.02 & 0.03 & -0.18 & -0.04 & -0.26 & \\
\hline 19 & & Family GENERATION in Control & 1.81 & 0.84 & 0.02 & 0.00 & 0.04 & 0.10 & -0.04 & 0.01 & -0.12 & -0.11 & 0.01 & 0.07 & 0.05 & 0.02 & -0.07 & -0.08 & 0.08 & 0.11 & 0.27 & -0.21 \\
\hline
\end{tabular}

Notes: $n=172$. Correlations greater than 10.191 are significant at $p<0.01$. Correlations greater than 10.14l are significant at $p<0.05$. 
TABLE 4: Structural model results and statistics

\begin{tabular}{|c|c|c|c|c|}
\hline & Hypotheses & $\begin{array}{l}\text { Unstandardised } \\
\text { Loading }\end{array}$ & $\begin{array}{l}\text { Standardised } \\
\text { Loading }\end{array}$ & $\begin{array}{l}\text { Robust } \\
t \text {-Value }\end{array}$ \\
\hline \multirow{2}{*}{ Model 1} & Family Social Capital $\rightarrow$ Performance & $1.04 * * *$ & $0.45^{* * *}$ & 4.59 \\
\hline & \multicolumn{4}{|c|}{$\begin{array}{c}S-B \chi^{2}(124 d f)=136.67(p=0.21) ; B B N F I=0.87 ; B B N N F I=0.98 ; C F I=0.99 ; I F I=0.99 ; M F I=0.96 ; \\
R M S E A=0.024 ; R^{2}=0.32\end{array}$} \\
\hline \multirow{2}{*}{ Model 2} & Non-Family Social Capital $\rightarrow$ Performance & $1.49 * * *$ & $0.46^{* * * *}$ & 3.64 \\
\hline & \multicolumn{4}{|c|}{$\begin{array}{c}S-B \chi^{2}(124 d f)=134.79(p=0.24) ; B B N F I=0.87 ; B B N N F I=0.98 ; C F I=0.99 ; I F I=0.99 ; M F I=0.97 ; \\
R M S E A=0.023 ; R^{2}=0.35\end{array}$} \\
\hline \multirow{4}{*}{ Model 3} & \multicolumn{4}{|c|}{ Non-Family Social Capital and Family Social Capital $\rightarrow$ Performance } \\
\hline & Family Social Capital $\rightarrow$ Performance & $0.57 * *$ & $0.24 * *$ & 2.07 \\
\hline & Non-Family Social Capital $\rightarrow$ Performance & $0.95 * * *$ & $0.30 * *$ & 2.40 \\
\hline & \multicolumn{4}{|c|}{$\begin{array}{c}S-B \chi^{2}(123 d f)=130.49(p=0.30) ; B B N F I=0.88 ; B B N N F I=0.99 ; C F I=0.99 ; I F I=0.99 ; M F I=0.98 ; \\
R M S E A=0.019 ; R^{2}=0.35\end{array}$} \\
\hline \multirow{4}{*}{$\begin{array}{l}\text { Model } 4 \\
\text { (Fully } \\
\text { Mediated) }\end{array}$} & \multicolumn{4}{|c|}{ Family Social Capital $\rightarrow$ Non-Family Social Capital $\rightarrow$ Performance } \\
\hline & Family Social Capital $\rightarrow$ Non-Family Social Capital & $0.43 * * *$ & $0.59 * * *$ & 3.42 \\
\hline & Non-Family Social Capital $\rightarrow$ Performance & $1.46^{* * *}$ & $0.46^{* * *}$ & 3.72 \\
\hline & \multicolumn{4}{|c|}{$\begin{array}{c}S-B \chi^{2}(129 d f)=140.69(p=0.23) ; B B N F I=0.87 ; B B N N F I=0.98 ; C F I=0.99 ; I F I=0.99 ; M F I=0.97 ; \\
R M S E A=0.023 ; R^{2}=0.34\end{array}$} \\
\hline \multirow{5}{*}{$\begin{array}{c}\text { Model } 5 \\
\text { (Partially } \\
\text { Mediated) }\end{array}$} & \multicolumn{4}{|c|}{ Family Social Capital $\rightarrow$ Non-Family Social Capital $\rightarrow$ Performance } \\
\hline & Family Social Capital $\rightarrow$ Non-Family Social Capital & $0.42^{* * *}$ & $0.56^{* * *}$ & 3.34 \\
\hline & Non-Family Social Capital $\rightarrow$ Performance & $0.94 * *$ & $0.29 * *$ & 2.53 \\
\hline & Family Social Capital $\rightarrow$ Performance & $0.57 * *$ & $0.24 * *$ & 2.15 \\
\hline & \multicolumn{4}{|c|}{$\begin{array}{c}S-B \chi^{2}(128 d f)=136.32(p=0.29) ; B B N F I=0.87 ; B B N N F I=0.99 ; C F I=0.99 ; I F I=0.99 ; M F I=0.98 ; \\
R M S E A=0.019 ; R^{2}=0.35\end{array}$} \\
\hline \multicolumn{5}{|c|}{ Note: $* * p<0.01 ; * * * p<0.001$} \\
\hline
\end{tabular}

TABLE 5: Nested model for comparisons and model statistics

\begin{tabular}{|c|c|c|c|c|c|c|c|c|c|c|}
\hline & & $\chi^{2}$ & df & p-Value & RMSEA & BBNNFI & CFI & IFI & MFI & $\mathbf{R}^{2}$ \\
\hline Model 4 & $\begin{array}{c}\text { Fully } \\
\text { Mediated } \\
\text { Model } \\
\end{array}$ & 140.69 & 129 & 0.23 & 0.023 & 0.98 & 0.99 & 0.99 & 0.97 & 0.34 \\
\hline Model 5 & $\begin{array}{c}\text { Partially } \\
\text { Mediated } \\
\text { Model } \\
\end{array}$ & 136.32 & 128 & 0.29 & 0.019 & 0.99 & 0.99 & 0.99 & 0.98 & 0.35 \\
\hline Fully ve & tially & $\Delta 4.37$ & $\Delta \mathbf{1}$ & $<0.05$ & & & & & & \\
\hline
\end{tabular}


FIGURE 1: Family social capital, non-family social capital, and firm performance (Model 5)

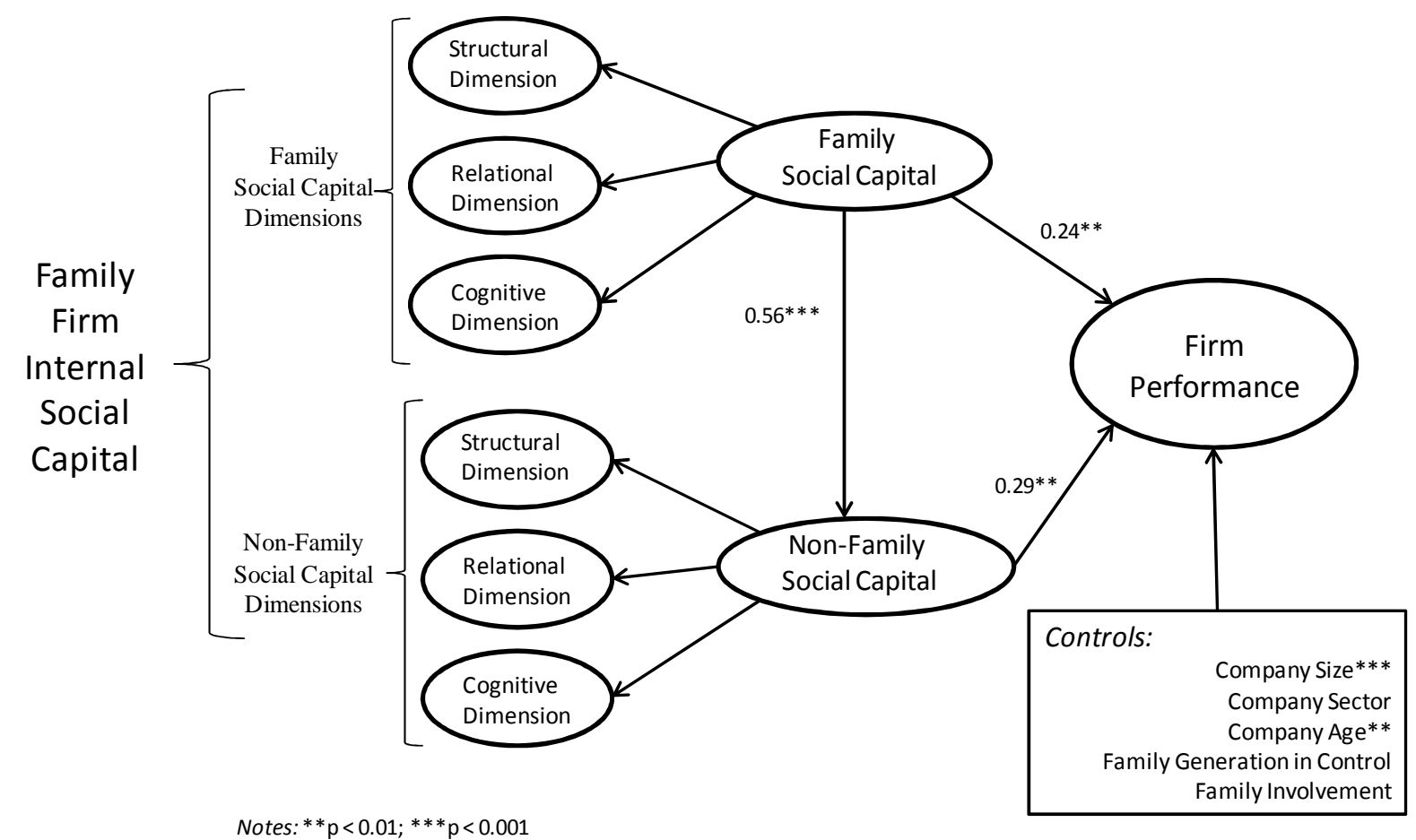




\section{APPENDIX I: Variables and Items}

\section{Measures: Family SC: $($ Likert 1-5) $(\alpha=0.78)$}

Please indicate your agreement with the following statements concerning the relationships between family members working in the family firm. For your rating, take into account that ' 1 ' is to express that you completely disagree and ' 5 ' that you completely agree.

STRUCTURAL DIMENSION $(\alpha=0.80)$

- Item 1: In general, family members who work in the company and /or are members of the board of directors also maintain relationships outside the company (dinners, clubs, ...)

- Item 2: In general, family members who work in the company and/or are members of the board of directors maintain close social relationships outside the company; that is, they collaborate with one another to solve company problems together.

\section{RELATIONAL DIMENSION $(\alpha=0.84)$}

- Item 3: In general, family members who work in the company and/or are members of the board of directors maintain close social relationships because they share information and rely on each other to conduct business.

- Item 4: In general, family members who work in the company and/or are members of the board of directors keep their promises and are loyal to the company.

\section{COGNITIVE DIMENSION $(\alpha=0.74)$}

- Item 5: In general, family members who work in the company and/or are members of the board of directors share the same ambitions, vision, and values.

- Item 6: In general, family members who work in the company and/or are members of the board of directors pursue the same objectives and mission.

Measures: Non-Family SC - Likert (1-5) $(\alpha=0.78)$

Please indicate your agreement with the following statements concerning the relationships between non-family members working in the family firm. For your rating, take into account that ' 1 ' is to express that you completely disagree and '5' that you completely agree.

STRUCTURAL DIMENSION $(\alpha=0.71)$

- Item 7: In general, non-family members who work in the company maintain relationships outside company (dinners, clubs, ...)

- Item 8: In general, non-family members who work in the company maintain close social relationships outside the company; that is, they collaborate with one another to solve company problems together.

\section{RELATIONAL DIMENSION $(\alpha=0.80)$}

- Item 9: In general, non-family members who work in the company maintain close social relationships because they share information and rely on each other to conduct business.

- Item 10: In general, non-family members who work in the company keep their promises and are loyal to the company.

\section{COGNITIVE DIMENSION $(\alpha=0.85)$}

- Item 11: In general, non-family members who work in the company share the same ambitions, vision, and values.

- Item 12: In general, non-family members who work in the company pursue the same objectives and mission.

\section{Measures FAMILY FIRM PERFORMANCE - Likert (0-10) $(\alpha=0.83)$}

Please indicate your agreement with the following two statements with respect to the family firm performance. For your rating, take into account that ' $O$ ' is to express that you completely disagree and ' 10 ' that you completely agree.

- Item 13: We have had a higher level of profitability than our close competitors during the last five years.

- Item 14: Our financial position has been better than that of our close competitors in the last five years. 